\title{
Detection of Leishmania infantum amastigotes in neutrophil from peripheral blood in a naturally infected dog
}

\author{
Detecção de formas amastigotas de Leishmania infantum em neutrófilos do \\ sangue periférico de cão naturalmente infectado
}

\author{
Gilsan Aparecida de Oliveira1,2* (1); Vitória Aline Santos Sarmento2; Ericka Wanessa da Silva Costa²; \\ Rômulo Pessoa-e-Silva'; Rayana Carla Silva de Morais'; Roberto Rômulo Ferreira²; Ana Paula Sampaio Feitosa; \\ Fábio André Brayner ${ }^{1,3}$; Luiz Carlos Alves ${ }^{1,3}$ \\ ${ }^{1}$ Laboratório de Biologia Celular e Molecular, Departamento de Parasitologia, Instituto Aggeu Magalhães, Fundação Oswaldo Cruz - \\ FIOCRUZ-PE, Pernambuco, PE, Brasil \\ ${ }^{2}$ Laboratório de Doenças Parasitárias, Centro Universitário CESMAC, Fundação Jayme de Altavila, Maceió, AL, Brasil \\ ${ }^{3}$ Laboratório de Imunopatologia Keizo Asami - LIKA, Universidade Federal de Pernambuco - UFPE, Recife, PE, Brasil
}

How to cite: de Oliveira GA, Sarmento VAS, Costa EWS, Pessoa-e-Silva R, Morais RCS, Ferreira RR, et al. Detection of Leishmania infantum amastigotes in neutrophil from peripheral blood in a naturally infected dog. Braz J Vet Parasitol 2021; 30(3): e004821. https://doi.org/10.1590/S1984-29612021060

\begin{abstract}
Canine visceral leishmaniasis (CVL) is a zoonotic disease of high lethality caused by Leishmania infantum in the Americas. In the infected dog, the amastigotes are scarce in blood, especially in the late phase of the disease. This study aimed to report a rare case of $L$. infantum amastigotes found in neutrophils from peripheral blood of a naturally infected dog in terminal phase of CVL, also describing its clinical status before and after treatment with miltefosine $2 \%$. The dog, which presented as polysymptomatic and with classical signs and symptoms of CVL was submitted to the following tests: Dual Path Platform (DPP) rapid test, ELISA and parasitological examination of peripheral blood. Hematological and biochemical parameters were obtained before and after treatment. All diagnostic tests were positive for CVL. The identification of L. infantum amastigotes inside neutrophils from peripheral blood was confirmed through microscopy, and the species was confirmed by molecular analysis. At the end of the treatment, peripheral parasitemia was not detected, and improvements were observed in clinical and laboratorial parameters. Finally, this atypical finding can be used as example to raise discussions about the real immunological role of neutrophils in late phases of CVL and its clinical/therapeutic implications.
\end{abstract}

Keywords: Canine visceral leishmaniasis, blood smear, peripheral blood, neutrophil, amastigote.

\begin{abstract}
Resumo
A leishmaniose visceral canina (LVC) é uma doença zoonótica de alta letalidade causada por Leishmania infantum nas Américas. No cão infectado, as formas amastigotas são escassas no sangue, principalmente na fase tardia da doença. Este estudo teve como objetivo relatar um caso raro de amastigotas de $L$. infantum encontradas em neutrófilos do sangue periférico de um cão naturalmente infectado e terminal da LVC descrevendo também seu estado clínico antes e após o tratamento com miltefosina a $2 \%$. O cão, que se apresentou como polissintomático e com sinais e sintomas clássicos da LVC, foi submetido aos seguintes testes: teste rápido Dual Path Platform (DPP), ELISA e exame parasitológico de sangue periférico. Os parâmetros hematológicos e bioquímicos foram obtidos antes e após o tratamento. Todos os testes diagnósticos foram positivos para LVC. A identificação de formas amastigotas de L. infantum, dentro de neutrófilos do sangue periférico foi confirmada por microscopia, e a espécie foi confirmada por análise molecular. Ao final do tratamento, não foi detectada parasitemia periférica, observando-se melhora dos parâmetros clínicos e laboratoriais. Por fim, esse achado atípico pode ser usado como exemplo para levantar discussões sobre o real papel imunológico dos neutrófilos nas fases tardias da LVC e suas implicações clínicas/terapêuticas.
\end{abstract}

Palavras-chave: Leishmaniose visceral canina, sangue periférico, esfregaço de sangue, neutrófilo, amastigota.

Received March 19, 2021. Accepted June 2, 2021.

*Corresponding author: Gilsan Aparecida de Oliveira. E-mail: deoliveira.gilsan@gmail.com 
Canine visceral leishmaniasis (CVL) is a zoonotic parasitic disease caused by Leishmania infantum which is initially phagocytized by neutrophils, and then by monocytes and macrophages, the latter being used as the host cell (Pereira et al., 2019). It is transmitted by female phlebotomine sand flies, which are infected after a blood meal, primarily in animals (Ribeiro et al., 2018). polymorphonuclear neutrophils are indispensable in the initial phase of infection, as they are able to eliminate the parasite by phagocytosis, through the generation of oxidative burst and extrusion of extracellular traps (Venuprasad et al., 2003; Wardini et al., 2019). At the same time, it is well discussed in literature that these cells are also associated with the establishment of the infection, since parasites developed mechanisms to circumvent the defense strategies elicited by neutrophils (Almeida et al., 2013; Wardini et al., 2019). In this context, neutrophils are not commonly involved in the late phase of $L$. infantum infection, being related to the acute inflammatory response observed in the early phase of the disease (Hurrell et al., 2016). In veterinary medicine, parasites were rarely detected in blood smears and CVL parasitemia is uncommon and even transitory (Giudice \& Passantino, 2011). The verification of neutrophils filled with amastigotes in the peripheral blood is very unusual, and even more difficult to visualize if the dog is in terminal CVL. This study aimed to report a rare case of $L$. infantum amastigotes found in neutrophils from peripheral blood of a naturally infected dog in terminal phase of CVL, also describing its clinical status before and after treatment with miltefosine $2 \%$.

A 2-year-old, female dog, mongrel, weighing $10.8 \mathrm{~kg}$, was attended at the Clinical School of Veterinary Medicine of the Cesmac University Center, in Maceió, Alagoas state. The dog had a history of diarrhea, vomiting, apathy and increased abdominal volume. From physical examinations, the following clinical signs were observed: hepatosplenomegaly, onychogryphosis, anorexia and abdominal pain.

The following complementary laboratory tests were requested: complete blood count (CBC), biochemistry and ultrasonography, and as diagnostic methods for L. infantum, immunochromatographic rapid test Dual Path Platform (TR-DPP ${ }^{\circledR}$ Bio-Maguinhos/FIOCRUZ, Rio de Janeiro, RJ, BR), Enzyme-Linked Immunosorbent Assay (ELISA) (EIE-LVC Bio-Manguinhos/FIOCRUZ, Rio de Janeiro, RJ, BR) and parasitological examination based on the search for parasites in stained smears, using an optical microscope (1,000x magnification). The real-time quantitative Polymerase Chain Reaction (qPCR) was performed using the LINF 1B system, which detects a 132 base pairs fragment of the kinetoplast DNA (kDNA) from Leishmania donovani Complex. The L. infantum genomic DNA standard curve (from $1.10^{6} \mathrm{fg}$ to $1 \mathrm{fg}$; dilution factor: 10 ) and the negative control (sample without DNA) were used as previously described by Paiva-Cavalcanti et al. (2009).

The sample was reactive for TR-DPP $®$ and ELISA with a cutoff of 0.371 . In the tests for parasitological diagnosis by blood smear, numerous amastigotes of $L$. infantum were observed parasitizing neutrophils (Figure 1 ) and with high parasite load in qPCR, with 220,359.94 fg of parasite DNA (Figure 2).

Rouleaux and target cells, metarubricytes, normocytic normochromic anemia (Erythrocytes: $2.52 \mathrm{million} / \mathrm{mm}^{3}$; Hemoglobin: 5.1g/dL; Hematocrit 16.5\%; MCV: 66u3; MCHC 30.6g/dL) leucopenia (Leukocytes $4.700 \mathrm{mil}^{3} / \mathrm{mm}^{3}$ ); thrombocytopenia (Platelets $57.960 \mathrm{mil} / \mathrm{mm}^{3}$ ), and elevated protein (Total proteins 10,2g/dL) were verified. In the biochemical analyses the following alterations were observed: hypercreatinemia, hyperuricemia, hypoalbuminemia, increased Alkaline phosphatase (ALP) and increased alanine transaminase (ALT) (Table 1). Ultrasound images demonstrated hepatosplenomegaly.

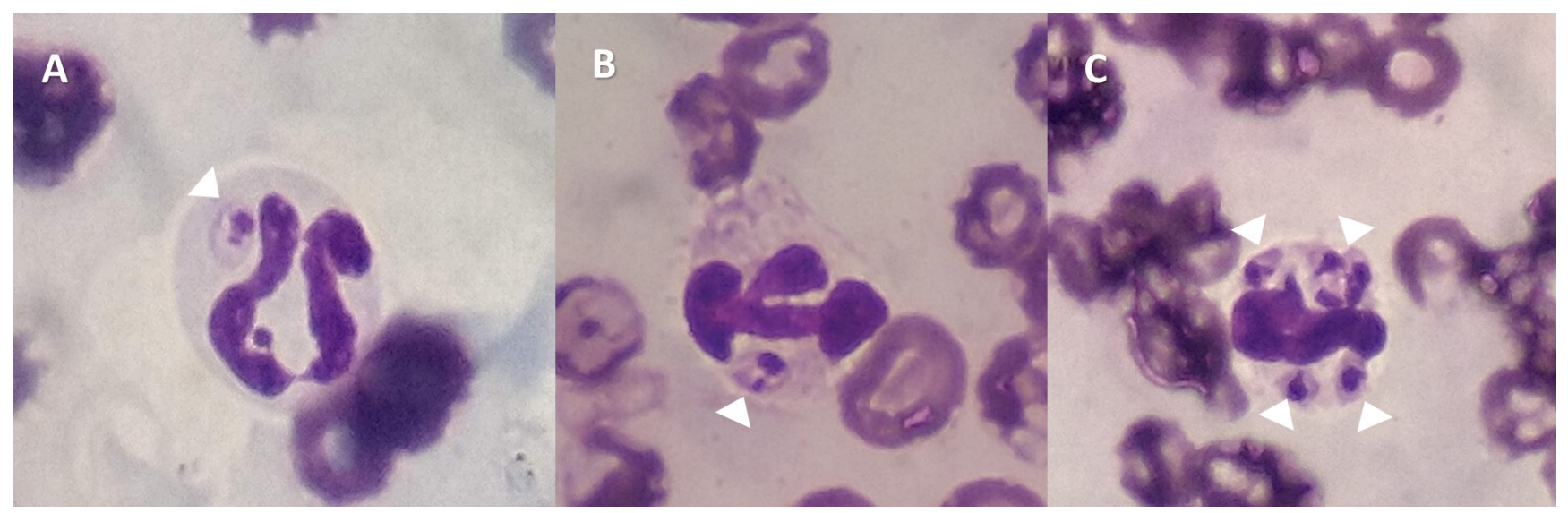

Figure 1. Leishmania infantum amastigotes found inside neutrophils from peripheral blood smears of a dog. 
A

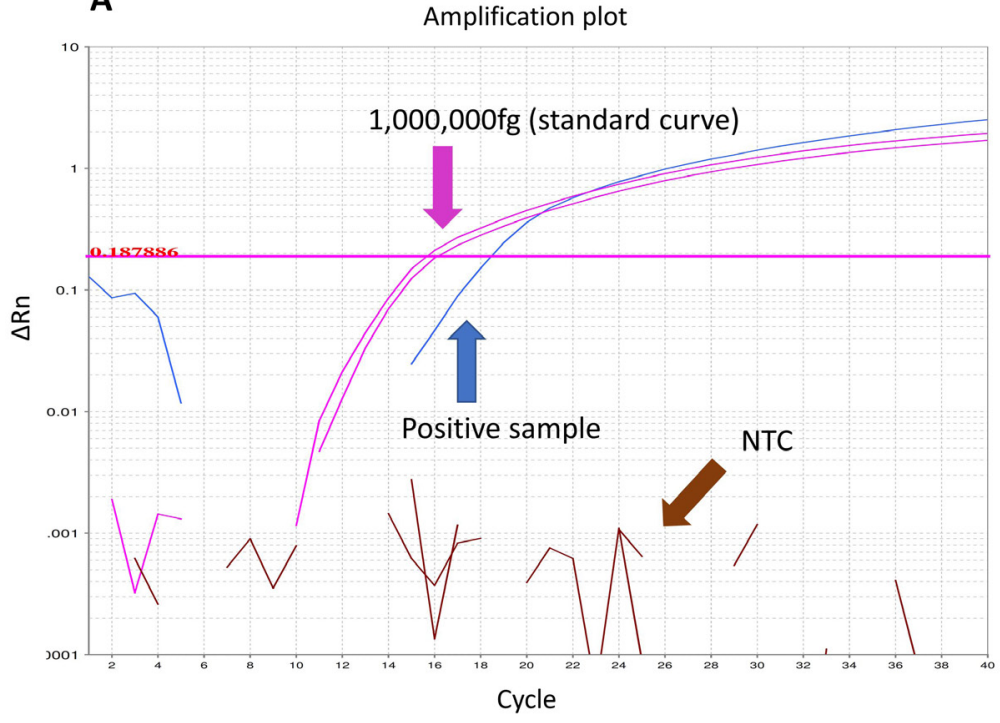

B

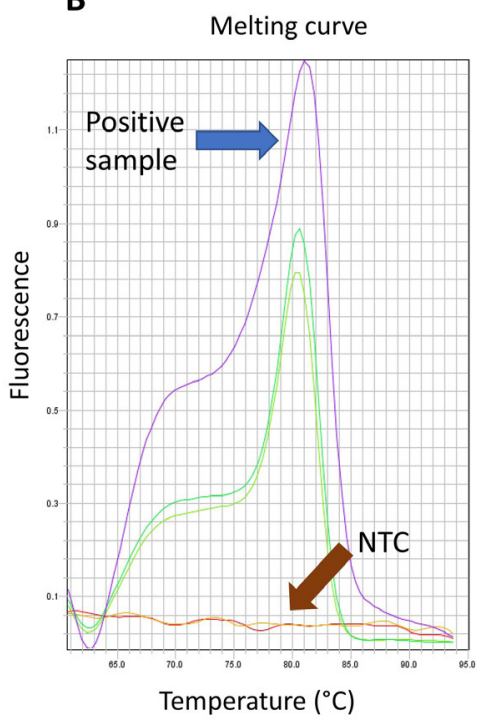

Figure 2. Detection of Leishmania infantum DNA by qPCR in peripheral blood from a dog. (A) Amplification curve in logarithmic scale; (B) Melting curve obtained from the positive sample, showing a melting temperature of approximately $81^{\circ} \mathrm{C}$. NTC: No Template Control.

Table 1. Biochemical exams done before after the treatment of a dog with $2 \%$ miltefosine.

\begin{tabular}{lccc}
\hline \multicolumn{1}{c}{ Biochemical Parameters } & \multicolumn{2}{c}{ Treatment } & Reference Values \\
\cline { 2 - 3 } & Before & After & $7.0-92.0$ \\
Alanine aminotransferase (ALT) $\left(\mathrm{UI} \mathrm{L}^{-1}\right)$ & 298 & 36 & $0.5-1.6$ \\
Creatinine $(\mathrm{mg} / \mathrm{dL})$ & 2.02 & 2.67 & $10.0-160.0$ \\
Alkaline phosphatase $(\mathrm{ALP})\left(\mathrm{UI} \mathrm{L}^{-1}\right)$ & 350.1 & 162.7 & $10.0-60.0$ \\
Urea $(\mathrm{mg} / \mathrm{dL})$ & 111 & 272 & $6-8$ \\
Total proteins $(\mathrm{g} / \mathrm{dL})$ & 7.7 & 9.3 & $2.3-3.8$ \\
Albumin $(\mathrm{g} / \mathrm{dL})$ & 1.1 & 1.1 & $2.4-4.8$ \\
Globulins $(\mathrm{g} / \mathrm{dL})$ & 6.6 & 8.2 & 2.8 \\
\hline
\end{tabular}

This study was approved by the Animal Use Ethics Committee of Cesmac University Center with number 13A.2018. The guardian of the dog signed the free and informed consent term.

The dog was submitted to treatment with $2 \%$ miltefosine for 28 days and monitored during this period. As adjuvant therapy, a single dose of metoclopramide $0.3 \mathrm{mg} / \mathrm{kg}$ intramuscular was administered. At the end of the treatment, clinical improvement was observed, including restoration of appetite, absence of vomiting and diarrhea. There was no significant improvement in hematological parameters, with only a discrete increase in the number of platelets $\left(65.400 \mathrm{mil} / \mathrm{mm}^{3}\right)$, leukocytes $\left(12.000 \mathrm{mil} / \mathrm{mm}^{3}\right)$, and neutrophils $(86 \%)$. At the end of treatment, it was possible to verify by biochemical analysis (ALT and ALP) a decrease in hepatic enzymes levels. However, as for analytes related to renal function, increasing in urea and creatinine levels was verified, indicating greater renal damage after treatment.

Previous studies have already described the presence of amastigotes in the peripheral blood. For example, Santos et al. (2006) identified L. infantum amastigotes in peripheral blood and in synovial fluid of a dog, causing splenomegaly and polyarthritis. Giudice \& Passantino (2011), who studied 1,438 dogs, observed L. infantum amastigotes in blood smear from only four $(0.28 \%)$ animals. The authors related the presence of $L$. infantum in peripheral blood of dogs with lethargy and anorexia in a severe state of the disease. Several hematological alterations such as anemia, thrombocytopenia, neutrophilia and monocytosis, in addition to hepatosplenomegaly, were present in the four animals. Such results corroborate with the present study regarding the clinical presentation 
observed in the final phase of the disease. The presence of $L$. infantum in mononuclear cells of the liver and spleen may cause hypertrophy and hyperplasia of these organs (hepatosplenomegaly), and this can lead to important hematological alterations (Honse et al., 2013).

The marked degree of hepatosplenomegaly indicates the terminal phase of the disease, with the presence of amastigotes in the viscera and low parasitemia in peripheral blood (Brasil, 2014). he molecular test, however, indicated a high parasitemia in the dog. The hepatosplenomegaly confirmed at clinical examination and in ultrasound images, associated with peripheral parasitemia, may be consequence of the abundance of the mononuclear phagocyte system (MPS), which is essential for long-term survival of the parasite (Giunchetti et al., 2008; Saridomichelakis, 2009).

As previously commented, alterations in red and white blood cells were found in the dog. According to Reis et al. (2006), severe anemia was observed in their study in 16 naturally infected, symptomatic dogs, with significant decreases in the number of erythrocytes, hemoglobin, and hematocrit. Regarding white blood cells, a significant decrease was observed significant decrease of all cellular subtypes, including leukocytes, monocytes, lymphocytes, and eosinophils. Freitas et al. (2012) examined 68 symptomatic dogs with varying clinical severity. Were observed changes in the red and white series: reductions in red blood cells (63\%), hematocrit (72\%), and hemoglobin (62\%), as well as leukocytosis (33\%), neutropenia (28\%) and thrombocytopenia (50\%). Our findings corroborate with the authors regarding the red and white series. All values obtained for the different hematological parameters are inside the ranges found by Freitas et al. (2012). We observed a slight increase in the number of neutrophils. This finding is in accordance with Paltrinieri et al. (2016), who considers the increase in neutrophils in the blood of infected dogs a frequent finding. Thrombocytopenia was also observed, which is a characteristic of the final phase of CVL. This observation corroborates with the findings of Terrazzano et al. (2006), who observed thrombocytopenia associated with the severe state of a dog naturally infected with L. infantum. Hence, the alterations found in the hematological examination before treatment are in accordance with a typical CVL in final phase, without eye-catching findings which could be associated with the parasitized neutrophils found in peripheral blood.

As commented, the biochemical and hematological parameters were also examined after the therapeutical scheme. In a study performed with naturally infected dogs, Santos et al. (2019) performed an analysis pre- and posttreatment with miltefosine associated with allopurinol. Discrete difference was found in the red series with values within the standard, however with variations that may be below the reference both before and after treatment. These results are in line with ours. In relation to the renal function post-treatment, it was interesting to observe that hematological levels of urea and creatinine increased, especially urea (from 111 to $272 \mathrm{mg} / \mathrm{dL}$ ) (Table 1). According to Bianciardi et al. (2009) and Miró et al. (2009), miltefosine is not associated with renal injury in treated dogs. Proverbio et al. (2016) verified that naturally infected dogs treated with miltefosine and allopurinol had proteinuria reduction, and urine protein:creatinine (UPC) ratio also reduced significantly. It is important to consider secondary causes that may have caused the increasing in urea and creatinine levels in blood, but this finding in a dog with high parasitemia in final phase of the disease is an interesting topic to be further investigated. Complementary exams such as urine assessment are pivotal.

Finally, the present study is an atypical case in which L. infantum amastigotes were found inside polymorphonuclear neutrophils from the peripheral blood of a dog with late CVL. This is the first study in Brazil to describe such uncommon finding, and it can be used as example to raise discussions about the real immunological role of neutrophils in late phases of CVL and its clinical/therapeutic implications.

\section{References}

Almeida BFM, Narciso LG, Bosco AM, Pereira PP, Braga ET, Avanço SV, et al. Neutrophil dysfunction varies with the stage of canine visceral leishmaniosis. Vet Parasito/ 2013; 196(1-2): 6-12. http://dx.doi.org/10.1016/j.vetpar.2013.02.016. PMid:23498648.

Bianciardi P, Brovida C, Valente M, Aresu L, Cavicchioli L, Vischer C, et al. Administration of miltefosine and meglumine antimoniate in healthy dogs: clinicopathological evaluation of the impact on the kidneys. Toxicol Pathol 2009; 37(6): 770-775. http://dx.doi. org/10.1177/0192623309344088. PMid:19690151.

Brasil. Ministério da Saúde. Manual de vigilância e controle da Leishmaniose Visceral [online]. 1. ed. Brasília: Ministério da Saúde; 2014 [cited 2021 Apr 20]. Available from: http://www.saude.ba.gov.br/wp-content/uploads/2019/05/2014-Manual-de-vigil\%C3\%A2nciae-controle-da-leishmaniose-visceral.pdf

Freitas JC, Nunes-Pinheiro DC, Lopes Neto BE, Santos GJ, Abreu CR, Braga RR, et al. Clinical and laboratory alterations in dogs naturally infected by Leishmania chagasi. Rev Soc Bras Med Trop 2012; 45(1): 24-29. http://dx.doi.org/10.1590/S003786822012000100006. PMid:22370824. 
Giudice E, Passantino A. Detection of Leishmania amastigotes in peripheral blood from four dogs -short communication. Acta Vet Hung 2011; 59(2): 205-213. http://dx.doi.org/10.1556/avet.2011.003. PMid:21665574.

Giunchetti RC, Mayrink W, Carneiro CM, Corrêa-Oliveira R, Martins-Filho OA, Marques MJ, et al. Histopathological and immunohistochemical investigations of the hepatic compartment associated with parasitism and serum biochemical changes in canine visceral leishmaniasis. Res Vet Sci 2008; 84(2): 269-277. http://dx.doi.org/10.1016/j.rvsc.2007.04.020. PMid:17604064.

Honse CO, Figueiredo FB, Alencar NX, Fátima Madeira M, Gremião IDF, Schubach TMP. Disseminated intravascular coagulation in a dog naturally infected by Leishmania (Leishmania) chagasi from Rio de Janeiro - Brazil. BMC Vet Res 2013; 9: 43. http://dx.doi. org/10.1186/1746-6148-9-43. PMid:23497531.

Hurrell BP, Regli IB, Tacchini-Cottier F. Different Leishmania Species Drive Distinct Neutrophil Functions. Trends Parasitol 2016; 32(5): 392-401. http://dx.doi.org/10.1016/j.pt.2016.02.003. PMid:26944469.

Miró G, Oliva G, Cruz I, Cañavate C, Mortarino M, Vischer C, et al. Multicentric, controlled clinical study to evaluate effectiveness and safety of miltefosine and allopurinol for canine leishmaniosis. Vet Dermato/ 2009; 20(5-6): 397-404. http://dx.doi.org/10.1111/ j.1365-3164.2009.00824.x. PMid:20178476.

Paiva-Cavalcanti M, Brito MEF, Souza WV, Gomes YM, Abath FGC. The development of a real-time PCR assay for the quantification of Leishmania infantum in canine blood. Vet J 2009; 182(2): 356-358. http://dx.doi.org/10.1016/j.tvjl.2008.05.018. PMid:18603455.

Paltrinieri S, Gradoni L, Roura X, Zatelli A, Zini E. Laboratory tests for diagnosing and monitoring canine leishmaniasis. Vet Clin Pathol 2016; 45(4): 552-578. http://dx.doi.org/10.1111/vcp.12413. PMid:27805725.

Pereira MA, Alexandre-Pires G, Câmara M, Santos M, Martins C, Rodrigues A, et al. Canine neutrophils cooperate with macrophages in the early stages of Leishmania infantum in vitro infection. Parasite Immuno/ 2019; 41(4): e12617. http://dx.doi.org/10.1111/ pim.12617. PMid:30735568.

Proverbio D, Spada E, de Giorgi GB, Perego AR. Proteinuria reduction after treatment with miltefosine and allopurinol in dogs naturally infected with leishmaniasis. Vet World 2016; 9(8): 904-908. http://dx.doi.org/10.14202/vetworld.2016.904-908. PMid:27651682.

Reis AB, Martins-Filho OA, Teixeira-Carvalho A, Carvalho MG, Mayrink W, França-Silva JC, et al. Parasite density and impaired biochemical/hematological status are associated with severe clinical aspects of canine visceral leishmaniasis. Res Vet Sci 2006; 81(1): 68-75. http://dx.doi.org/10.1016/j.rvsc.2005.09.011. PMid:16288789.

Ribeiro RR, Michalick MSM, da Silva ME, dos Santos CCP, Frézard FJG, da Silva SM. Canine leishmaniasis: An Overview of the Current Status and Strategies for Control. BioMed Res Int 2018; 2018: 3296893. http://dx.doi.org/10.1155/2018/3296893. PMid:29789784.

Santos M, Marcos R, Assunção M, Matos AJ. Polyarthritis associated with visceral leishmaniasis in a juvenile dog. Vet Parasitol 2006; 141(3-4): 340-344. http://dx.doi.org/10.1016/j.vetpar.2006.05.028. PMid:16824686.

Santos MF, Alexandre-Pires G, Pereira MA, Marques CS, Gomes J, Correia J, et al. Meglumine antimoniate and miltefosine combined with allopurinol sustain pro-inflammatory immune environments during canine leishmaniosis treatment. Front Vet Sci 2019; 6: 362. http://dx.doi.org/10.3389/fvets.2019.00362. PMid:31681815.

Saridomichelakis MN. Advances in the pathogenesis of canine leishmaniosis: epidemiologic and diagnostic implications. Vet Dermato/ 2009; 20(5-6): 471-489. http://dx.doi.org/10.1111/j.1365-3164.2009.00823.x. PMid:20178485.

Terrazzano G, Cortese L, Piantedosi D, Zappacosta S, Di Loria A, Santoro D, et al. Presence of anti-platelet IgM and IgG antibodies in dogs naturally infected by Leishmania infantum. Vet Immunol Immunopatho/ 2006; 110(3-4): 331-337. http://dx.doi.org/10.1016/j. vetimm.2005.11.001. PMid:16406554.

Venuprasad K, Chattopadhyay S, Saha B. CD28 signaling in neutrophil induces T-cell chemotactic factor(s) modulating T-cell response. Hum Immunol 2003; 64(1): 38-43. http://dx.doi.org/10.1016/S0198-8859(02)00689-4. PMid:12507813.

Wardini AB, Pinto-da-Silva LH, Nadaes NR, Nascimento MT, Roatt BM, Reis AB, et al. Neutrophil properties in healthy and Leishmania infantum-naturally infected dogs. Sci Rep 2019; 9(1): 6247. http://dx.doi.org/10.1038/s41598-019-42687-9. PMid:31000764. 